\title{
Long-term Change in African Drylands: Can Recent History Point Towards Development Pathways?
}

\author{
MICHAEL MORTIMORE`
}

ABSTRACT The problem of poverty in Africa was often discussed in terms of the agro-ecological specifics and the internal social relations of societies, production systems and economies. It appeared necessary, therefore, for states and international organizations to intervene. Because poverty was identified with production constraints, such interventions took the form of technological transfer in agriculture. Later, as agro-ecological constraints became more widely perceived, and supposedly "fragile" ecosystems were believed to be under threat from population growth and other factors, emphasis shifted to "environmental sustainability". As with the new technologies, so with sustainable natural resource management, it was often assumed that the new knowledge must come from outside, or from "science", and must be promoted against the natural "conservatism" of smallholders by whatever means necessary-from coercion at one extreme to "participation" at the other. Recently there has been much movement away from such stereotypical positions towards more subtle and varied statements of the problem. However, I believe there is still a lacuna with respect to the autonomy of the smallholder in the "fight against poverty". Intervention is still the name of the game, and receives far more attention than the resources or achievements of poor people themselves. Analyses of long-term trends in the management of resources at the village, regional and national levels in dryland Africa suggest that African farmers have made considerable achievements in the face of a trying environment. An understanding of this long-term trend may provide a better framework for the diagnosis of current problems and the formulation of future policy on poverty and livelihoods in the drylands.

\section{Introduction: Three Narratives}

For many years the problem of poverty in rural Africa was discussed in terms of the agro-ecological specifics and the internal social relations of societies, production systems and economies. It appeared necessary, therefore, for states and international organizations to intervene. Because poverty was identified with production constraints, such interventions took the form of technological transfer in agriculture (including crop and livestock production). Words such as "modernization" gained currency. Later, as agro-ecological constraints became more widely perceived, and supposedly "fragile" ecosystems were believed to be under threat from population growth and other factors,

\footnotetext{
${ }^{\star}$ Michael Mortimore, Drylands Research, Milborne Port, Somerset.

In addition to those mentioned in note 4 , I should like to acknowledge the contribution made by Mary Tiffen to the ideas expressed in this paper, based on collaborative work undertaken with scientists in Kenya (University of Nairobi), Senegal (Institut Sénégalais de la Recherche Agricole), Niger (Abdoul Moumouni Université) and Nigeria (Ahmadu Bello University), and funded by UK Department for International Development.
} 
emphasis shifted to "environmental sustainability". As with the new technologies, so with sustainable natural resource management, it was often assumed that the new knowledge must come from outside, or from "science", and must be promoted against the natural "conservatism" of smallholders by whatever means necessary-from coercion at one extreme to "participation" at the other. Recently there has been much movement away from such stereotypical positions towards more subtle and varied statements of the problem. However, I believe there is still a lacuna with respect to the autonomy of the smallholder in the "fight against poverty". Intervention is still the name of the game, and receives far more attention than the resources or achievements of poor people themselves. Many interventions in the rural sector having failed (at great cost), is it time to look more analytically at those resources and achievements? Can they be mobilized to better effect? ${ }^{1}$

There are three narratives linking rural poverty, natural resources and social change in Africa: these are the "failing Africa", "intensifying Africa" and a "social anthropologists' Africa" narratives.

\subsection{Failing Africa}

While some regions of the world are reported to be "on target" towards the Millenium Development Goal (MDG) of reducing the proportion of their population living in "dollar poverty" by a half by 2015, Africa is getting worse. In terms of food sufficiency, Africa is said to import increasing amounts of its food. Since the 1970s, large quantities of foreign exchange have been so used, and some countries became "food aid dependent". Recurring famines remind the world that food insecurity and starvation are nowhere near to being abolished. Environmental indicators appear to show degradation on a huge scale, apparently as the result of productive activities, with the implication that population growth is unsustainable. Conflict and HIV/AIDS threaten to destroy the institutional and economic basis of agriculture and decimate labour and skills. The long-term sustainability of the social and economic fabric is said to be in doubt.

\subsection{Intensifying Africa}

In response to a neo-Malthusian perspective on social and environmental change, several authors have advanced "Boserupian" hypotheses of agricultural intensification driven by increasing rural population densities. In such a view, technological transfers from outside play a subsidiary role to the uptake of indigenous or hybrid technologies already known in the system, but requiring additional inputs of labour. In Machakos District, Kenya, population density growth worked, together with other critical factors, to produce a trajectory of change that saw a population that multiplied nearly six fold, 1930-90, increase agricultural productivity per head nearly fourfold and per hectare elevenfold (Tiffen et al., 1994). The management of natural resources had meanwhile become more, not less, sustainable. The other factors were: improved access to markets, provided by urbanization and the export of high-value commodities; new or adapted technologies; migration to new lands; income diversification; investments in education to secure wage employment; investments in land, its acquisition, conservation and productivity; and flexible social organizations and institutions.

In a number of other areas, smallholders have intensified, integrated crop with livestock production, and sustained output on a decadal time-scale while controlling degradation (Turner et al., 1993). A model of the transition from extensive to intensive land use has been advanced (Mortimore, 1998). 


\subsection{A "Social Anthropologist's Africa"}

Anthropologists have tended to resist model-based approaches. It can be argued that both neo-Malthusian and "Boserupian" models (Boserup, 1965) imply a degree of determinism that gives insufficient scope for adaptation or individuality. It is claimed that social determinants of behaviour should not be given second place to economic drivers. A general model appears to deny the specifics of time and place and the huge diversity of individual or community trajectories of change. Village-level studies have demonstrated the rationality and integrity of these anthropological perspectives Development interventions have often been criticized for focusing on economic or technical targets to the exclusion of structural and behavioural dimensions which may eventually frustrate the uptake of new technologies. Not only the definition of "development" but also its progression should be placed in social context.

It is a paradox that notwithstanding the popularity of the failing Africa narrative, poor rural Africans in many areas continue to demonstrate a capacity to produce more food, supply urban labour, educate themselves, endure oppression and deprivation and reconstruct broken economic or social systems. ${ }^{2}$ It is from trying to understand how poor people manage their livelihoods and their natural resources in conditions of great difficulty that science can learn to make itself more useful to them. My own experience has been largely confined to drylands in West Africa and Kenya (Mortimore, 1998), and I justify my focus on such drylands on the ground that it is there that nature's greatest constraints (low productivity and high variability) have to be managed. ${ }^{3}$

I proceed by briefly reviewing some data from the village, district and national levels, which suggest that the popular diagnosis of rural African crisis may be in error, or at least oversimplified to the point of being misleading. I then pursue three questions:

(1) What is the nature of the resource that has enabled rural Africans to sustain themselves through shocks and adverse trends?

(2) What are the constraints?

(3) Can a better understanding of it contribute to policies, interventions, or governance?

I am aware that to suggest that some of the poorest people may be a part of the solution, rather than merely the problem, will appear radical to those accustomed to thinking of them either as helpless victims or as agents of degradation. I cannot answer this question (yet), but I am convinced that until Africans are accorded equality in global citizenship, sustainable development (whatever that expression means) may continue to elude us.

\section{Some Evidence from Drylands}

\subsection{Shocks and Trends}

Besides living with natural resource endowments that offer, on average, low productivity potential, rural dryland people have to manage the impact of unpredictable shocks from a wider range of sources, and having greater potential severity, than inhabitants of the humid tropics and temperate marginal climate zones, where most of the world's major population concentrations live (Anon., 1997). These sources are summarized in Table 1. These risks are not exclusive to drylands, but when overlaid by extreme poverty, and (as often) by geographical inaccessibility, they can be intensified by a reduced capacity to manage them by means of self-insurance (through financial, 
Table 1. Sources of risk

\begin{tabular}{|c|c|c|c|c|}
\hline Climatic & Ecological & Economic & The state & Accident \\
\hline $\begin{array}{l}\text { Intra-seasonal } \\
\text { drought }\end{array}$ & $\begin{array}{l}\text { Grasshoppers, } \\
\text { locusts, birds }\end{array}$ & $\begin{array}{l}\text { Exchange rate } \\
\text { over-valuation }\end{array}$ & $\begin{array}{l}\text { Changes in } \\
\text { taxation policy }\end{array}$ & $\begin{array}{l}\text { Mortality, } \\
\text { morbidity }\end{array}$ \\
\hline Annual drought & $\begin{array}{l}\text { Rodents, } \\
\text { baboons }\end{array}$ & $\begin{array}{l}\text { Input price, } \\
\text { supply } \\
\text { constraints }\end{array}$ & $\begin{array}{l}\text { Changes in } \\
\text { duties or } \\
\text { subsidies }\end{array}$ & $\begin{array}{l}\text { Divorce, } \\
\text { disputes, courts }\end{array}$ \\
\hline \multirow[t]{2}{*}{ Storm, flood } & $\begin{array}{l}\text { Livestock } \\
\text { disease }\end{array}$ & $\begin{array}{l}\text { Fuel and } \\
\text { general } \\
\text { inflation }\end{array}$ & $\begin{array}{l}\text { Non- } \\
\text { consultative } \\
\text { legislation }\end{array}$ & Fire \\
\hline & Crop viruses & Market failures & $\begin{array}{l}\text { Land } \\
\text { appropriation }\end{array}$ & $\begin{array}{l}\text { Civil disorder, } \\
\text { police }\end{array}$ \\
\hline $\begin{array}{l}\text { Long-term } \\
\text { rainfall decline }\end{array}$ & $\begin{array}{l}\text { Erosion, } \\
\text { degradation }\end{array}$ & $\begin{array}{l}\text { Falling export } \\
\text { demand }\end{array}$ & $\begin{array}{l}\text { Withdrawal of } \\
\text { services }\end{array}$ & $\begin{array}{l}\text { Cash flow (for } \\
\text { timely inputs) }\end{array}$ \\
\hline
\end{tabular}

accumulative, or social claim strategies). Damage may also be accentuated on account of the necessary compression of agricultural activity within a short growing season.

At the root of risk in dryland environments is long-term change in rainfall-as experienced in the Sahel from the 1960s to the 1980s, which exceeded in magnitude that predicted in climate change scenarios-and inter-year variability, which in a context of long-term decline means an increasing frequency of negative departures from the mean, and of agricultural drought (Hulme et al., 2001; Mortimore, 2000). However, considerable uncertainty surrounds the evidence of a recovery in Sahelian rainfall during the 1990s, and it should be recognized that Sahelian patterns do not apply to eastern or southern Africa.

Negative ecological or economic trends expose poor people to increased vulnerability to shocks. Much has been done, conceptually and methodologically, to define and map vulnerability (Downing et al., 1988). Such work focuses attention, quite properly, on deprivation and on the constraints acting on livelihood development. There has also been much work done on adaptive livelihood strategies, often called (inadequately) "coping strategies" (Davies, 1996). However, the point where vulnerability and adaptive capacity meet is ill-defined and poorly understood, though its strategic importance is obvious.

\subsection{Village Level: Kano Region, Nigeria}

Much has been written about the village communities in the region around Kano in the north of Nigeria (Mortimore, 1993; Mortimore et al., 1999; Mortimore \& Adams, 1999). ${ }^{4}$ The city of Kano, with its population of about 1.5 million, sits in the centre of a densely populated and closely farmed region where over 10 million rural people raise crops and livestock. This historic Kano Close-Settled Zone (KCSZ) forms the centre of a much larger region that Kano city dominates commercially, culturally and formerly politically, that extends over central northern Nigeria and southern Niger. With an average annual rainfall ranging from $800 \mathrm{~mm}$ in the extreme south to $450 \mathrm{~mm}$ in the north, and having rather finer textured though also sandy desert-edge soils, the KCSZ enjoys better agro-ecological potentials; but it has suffered the same decline in rainfall and increased frequency of drought, and has experienced long-term demographic growth such that farming population densities now exceed 220 persons $/ \mathrm{km}^{2}$ in some local government areas, and more than $80 \%$ of the surface has been under cultivation 
Table 2. Some implications of intensification

\begin{tabular}{ll}
\hline Agricultural micro-investments & Livestock operations \\
\hline Land clearance & Supervising grazing animals \\
Livestock fencing & Maintaining corrals \\
Soil amelioration & Cut-and-carry: browse, weeds, field borders \\
Tree planting and protection & $\begin{array}{l}\text { Residue collection, cartage, storage, } \\
\text { security; purchase of fodder, supplements }\end{array}$ \\
Terracing, stone lines, drains, ridging & Water fetching, storage, well-digging \\
Storage structures, pens, poultry houses & Milking, marketing \\
Small livestock (ruminants, birds, fish, etc.) & Health and breeding \\
\hline
\end{tabular}

every year since 1957 or earlier. Kano Hausa farmers are famous throughout Nigeria for their intensive and market-oriented agriculture and commercial capacities. State policy promoted groundnut and cotton production for export in the 1960s, but fell into a vacuum when rosette disease and drought demolished the prospects of the groundnut from 1975 and poor prices undermined those of cotton. However, a rapid growth in domestic demand fuelled by the oil boom drove a spontaneous switch to food crops, which took off with the introduction of a coherent agricultural policy in $1986 .{ }^{5}$ Meanwhile, livestock holdings, meat and milk production and marketing have increased in the long term.

Agricultural intensification in a dryland context is about optimizing the value of three inter-related factors: labour, capital and livestock. Some data collected on labour allocations during the short farming season (3-5 months) in northern Nigeria illustrate both the flexibility and efficiency of farming and livelihood systems. Family labour is allocated flexibly to the main farm operations, in response to rainfall which is highly variable and determines the configuration of the growth cycle. Despite the very high rural population density, there is not enough labour both to weed and to harvest at the same time, so late crops (sorghum, cowpea, groundnut) must be neglected while early ones (pearl millet) are cut. The amount of labour available constrains the scale of labour inputs - for example, the number of rounds of weeding that a farmer may attempt - and thus the intensity of farming. In this Sudanian farming system, with an on-farm population density of over 200 persons $/ \mathrm{km}^{2}$, labour inputs may peak much higher than in a Sahelian one with only 43 persons $/ \mathrm{km}^{2}$. In addition, labour is needed for many other tasks (Table 2). Both systems, however, produce plant biomass at levels similar to those found in natural vegetation under the same rainfall.

Models of rangeland biomass developed in the Mali Sahel (Breman \& de Wit, 1983) show a direct relationship with rainfall. Farmers in our Sudanian and Sahelian villages performed quite favourably by comparison. Livestock (small ruminants, plough bulls, donkeys or horses, fowls and a few cattle) are critical and labour has to be allocated to their care, more especially in the Sudanian village where every animal must be coralled day and night while the crops are growing. This labour reaches a peak during July-August and competes directly with weeding and harvesting work on the crops. The animals, besides providing milk or meat for market, draft energy and savings, recycle nutrients by consuming crop residues, weeds and tree foliage, and the reward is a supply of organic fertilizer which has long sustained the practice of annual cultivation. The key chemical nutrients in farmers' field topsoils may change little over periods of a decade or more, and when they do, it is the consequence of a farmer's inability to secure enough manure (or, in recent years, small supplementary amounts of mineral fertilizers). 
Some observers believe that intensification (analysed in greater detail elsewhere (Harris, 1996, 1998)) has gone as far as it can go in the KCSZ, and that only worsening poverty, resource degradation and a flight from the land can ensue. It is apt to point out that similar sentiments were being expressed 37 years ago (Trevallion, 1965). There are no satisfactory data on long-term crop yields, but as natural increase is not fully balanced by out-migration (Hill, 1977), the demand for food and incomes at the farm level may exceed the capacity even of an ecologically sustainable production system. The Kano region has a long historical record of income diversification through craft specialization, trade and short-term migration. Given the data available, it is impossible to say in quantified terms whether, at the regional level, households depend more than before on such incomes; but this seems likely. Diversification may be conceived in steps of increasing detachment from crop production. However, strong circularities bind these steps back to the natural resource base. Investments, knowledge and networks may be necessary to embark on diversification. Every rural household participates in some form of off-farm activity, and even every adult, including women. Permanent out-migration from the KCSZ is suggested by the fact that long-term population growth tended to fall behind rates of natural increase found elsewhere, and actual landlessness is rather rare.

Studies conducted at this scale tend not to support the macro-scale scenarios of rural African decline or collapse, not at least in West Africa, though poverty there certainly is a major problem (Wiggins, 2002). Strategic armouries designed on the basis of centuries-old experience are not exhausted yet, and a capacity to adapt to new situations has been documented (Davies, 1996; Mortimore \& Adams, 2001). Flexibility in dealing with day-to-day decisions in allocating the factors of production, labour in particular, can be distinguished from longer term adaptive capability, which is shown in reconfigurations year by year of the household's livelihood system. In northern Nigeria, the fulcrum of this balancing process is the harvest season, when food security is assessed and decisions about short-term migration or other strategies are made (Mortimore, 1989). On the other hand, some observers have argued that adaptive systems in the Sahel suffered structural disablement, through pressures imposed by colonial taxation, export agriculture, drought and other factors, to the extent of facing imminent collapse (e.g. Copans, 1975; Watts, 1983). Open market policies may increase this risk. The evidence from these dryland studies does not support such a view of imminent collapse.

\subsection{District Level: Kano Region, Nigeria}

The villages briefly referred to earlier are situated in the KCSZ (cf. Ariyo et al., 2001; Mustapha \& Meagher, 2000), whose demographic growth is best appreciated by comparing the patterns of population density generated by the censuses of 1931 and 1991. Not only do these contrasted patterns suggest a dramatic increase in the labour-to-land ratio, but also an increase in demand, especially if we consider that the recorded population of urban Kano increased from 96805 in 1931 (4\% of the provincial population) to 1364300 in 1991 (16\%) (Tiffen, 2001), and is now thought to be approaching 2 million. Farmers in this zone provision urban Kano only to a small extent, as the city can draw on a wider hinterland; nevertheless, this hinterland supplied the basic grain (millet) at declining real prices from the 1970s to the 1990s, and livestock at declining prices through much of the 1990s (Ariyo et al., 2001).

There have been repeated changes in nominal prices, in input subsidy policy, import protection and marketing structures (though food commodities have, for the most part, 
remained free from state intervention (Mustapha \& Meagher, 2000)). Other costs, in particular that of fuel, have fluctuated wildly. There have been several major civil disorders. There is no evidence that the source areas for Kano's grain and meat markets have seen major change since a benchmark in 1966-67. Yet in these areas, the rural populations (and their subsistence requirements) have doubled, and average rainfall in the northern part of the hinterland declined by a quarter or a third from the 1960s to the 1980s. Such a performance is not consistent with expectations based on an alleged major failure, both in the agricultural sector and in sustainable natural resource management (an observation that, in major respects, applies to the unjustly maligned Nigerian agricultural sector as a whole).

\subsection{District Level: Maradi Department, Niger Republic}

The Department of Maradi is our next district-level case (Mortimore et al., 2001). It is situated north-east of Kano and adjacent to the Nigerian border, extending northwards into areas too dry for farming. ${ }^{6} \mathrm{~A}$ second major force affecting the performance of the smallholder agricultural sector in this part of Africa was the decline in average rainfall which occurred from the 1960s until the 1990s, illustrated in the records for Maradi, which show persistent drought especially in the early 1970s and the 1980s. It is necessary to evaluate production against this background.

Population densities decline from $>50$ to $<20$ persons $/ \mathrm{km}^{2}$, and although there were established settlements by the mid-19th Century, the northern villages were mostly populated in a great rush of land-hungry migrants after the settlement of French colonial rule, up to the 1980s. Cultivation accounted for 59\% of the surface in 1975 and $73 \%$ by 1996 . The revision of land tenure in favour of private appropriation (Code Rurale) has motivated fresh enthusiasm to take land into cultivation, leaving very little residual pasture or woodland. According to a thorough analysis of natural resource management carried out in 1978-85, these pressures were responsible for widespread degradation of the soils and natural vegetation; moreover, "commoditization" seemed to threaten the economic and social sustainability of the production systems themselves (Grégoire \& Raynaut, 1980; Raynaut, 1975; Raynaut et al., 1988). During the past 40 years, agricultural policy has shifted through phases of export promotion or "modernization" (1960-74), food "self-sufficiency" financed with uranium revenues (1974-84) and structural adjustment (from 1985).

Maradi managed to maintain per capita output of cereals from 1964 to 1998, at levels well above estimated nutritional requirements, in most years, assuming that projected population data are correct (there was no census until 1977). Part of this requirement was supplied by extending the area planted from 1987 to 1995, but before and after those years, the changes in area were not significant. The alternative explanation is intensification. Surprising as this may seem, where risk is high, yields low (often $<100 \mathrm{~kg} / \mathrm{ha}$ ) and distances to market costly, a disaggregation of northern (drier) and southern (wetter) arrondissements shows that in the south, where land is scarcer, population densities higher and markets nearer, a positive yield trend may be emerging, whereas in the north, the extensive phase has not yet been concluded. In the south, there is more intensive interaction with Nigerian cross-border markets: livestock, human labour and tiger nuts are exported, while millet has been traded either way depending on exchange rates and harvests. Increasingly significantly, off-farm incomes have been sought in the more buoyant, urbanized economy of Nigeria. Again we cannot quantify this side of the equation; but with regard to natural resource management, there are suggestive indicators that a transition is occurring from an extensive, "soil- 
mining" mode of production to an intensifying, more sustainable one. The data series are supported by local evidence of significant practices in land tenure, tree management, soil fertility management, cropping and agronomy at the village and farm scale.

\subsection{District Level: Diourbel Région, Senegal}

This region is situated in the heart of the "peanut basin" or bassin arachidier where populations of Sereer or Wolof peasant farmers traditionally produced groundnuts for the export market (Faye et al., 2001). Although receiving, on average, only $400 \mathrm{~mm}$ of rain a year, and having seen a decline which is equivalent to a southward movement of the isohyets of $80-100 \mathrm{~km}$ between the $1950 \mathrm{~s}$ and the $1980 \mathrm{~s}$, the sandy soils of this region support rural population densities ranging from 46 to 151 persons $/ \mathrm{km}^{2}$, and more than $80 \%$ of the surface has been cultivated since 1954 or earlier. Senegal's prominence as an exporter of groundnuts was achieved by the provision of state agricultural credit, seed, input subsidies, extension and marketing services and technological development, on which producers had become totally dependent. As agricultural investment was supplied by the state, and paid for from crop sales, rural people diverted private investments elsewhere-notably to urban property, commerce and short-term migration. Evidence was adduced to support the view that nearly a century of groundnut production for export mined the soil of nutrients and reduced the peasantry to a condition of dependency on the state, ever seeking to increase output in order to maintain family revenues (Copans, 1975). New lands had been deforested and put down to groundnuts by dara working communities under the direction of Mouride marabouts.

The replacement of the Programme Agricole by structural adjustment policies (Nouvelle Politique Agricole) in the mid-1980s created a crisis in the agricultural sector. Notwithstanding a large urban demand for food (Dakar and Touba contain more than a third of Senegal's population), a taste for imported low-grade rice deliberately fostered by the French in colonial times acted as a major constraint on the markets for local cereals. It is not surprising in the circumstances that grain yields per capita declined in Diourbel Region, 1960-96, as well as those of groundnuts. However, yields per hectare showed distinct trends: while those for groundnuts declined, those for millet and sorghum (combined) were stable in the long term, though very variable from year to year.

This suggests a reordering of producers' priorities. Interestingly, yields per millimetre of rainfall showed parallel trends: downwards until the early 1970s, strongly improving until the mid-1980s, indicating agronomic improvements, and then stagnation (millet) and decline (groundnuts) until the early 1990s. Livestock numbers show improvements sustained throughout the period, though at the cost of a significant shift from cattle to small ruminants. These trends show the importance attached to investments in animals - of agricultural profits when times are good, and for security when times are bad. Increased interest in livestock was fuelled by a strong upward trend in prices for meat throughout the period, especially after devaluation of the CFA franc diminished imports. Significant developments in the production of commercial fodder, fruit and some minor crops in recent years show that Senegalese farmers are searching for profitable alternatives to the groundnut, but apart from investing in more animals (which must, of course, be fed), dryland families still prefer to divert their financial resources from agricultural investments to the generation of off-farm incomes. Greater Dakar (which contains about one-third of the population of Senegal) and the rapidly growing Mouride city of Touba attract both migrant and capital flows from the 
countryside. Families have, on average, one member away on migration, and the proportion of income earned from migration has increased since the 1960 s (Faye \& Fall, 2000).

These examples of adaptive change in Senegal, a country where agriculture is considered to be severely depressed, suggest that the capabilities of smallholders should not be underestimated.

\subsection{National Level: Six Countries}

National agricultural statistics, as provided to the FAO for its standardized global database, ${ }^{7}$ may justify scepticism with regard to African countries. Data collection varies in quality, and in some series even a casual reading shows that estimates were substituted for data, and not well-considered estimates at that. However, they provide the only quantitative narrative of long-term change, and are frequently cited in international documents, which in turn influence policy. It is worth asking, therefore, whether they uphold the "failing Africa" diagnosis. From a reconnaissance survey of the published series for six West African states (Nigeria, Ghana, Côte d'Ivoire, Senegal, Mali, Niger) — which includes a large number of graphs-the few following are selected: ${ }^{8}$

(1) Total agricultural imports, six countries. Increased food imports are the basis for the view that Africa is failing to feed itself. Food can be assumed to make up most of agricultural imports. However, when expressed in terms of value per capita (the only way of making valid comparisons between countries), it may be seen that while imports got out of control during the period 1975-85, four of our six countries regained control by the mid-1980s, and thereafter imports remained consistently low at \$US10-15 per capita, a level which hardly suggests an excessive degree of import-dependency. The exceptions were Côte d'Ivoire (which, being West Africa's most successful agricultural exporter, could afford it) and Senegal (whose addiction to imported rice has been noted).

(2) Food production (net), six countries. The FAO's indices of net food production per capita, taking the different major food crops into account, also provide a corrective to the notion that African countries have been failing. They suggest an increasing stability from the 1970s, with significant growth in some countries in the 1990s. These data do not suggest a worsening food crisis.

(3) Millet yields per hectare, Nigeria. There are many crops grown in the six countries and there is no way of generalizing yield trends meaningfully. However, several key crops, according to these series, improved their yields over the 40 -year period. The series for millet yields in Nigeria are a case in point (though constant average yields shown for successive years indicate interpolations or estimates). The downward trend of the polynomial curve is due to suspiciously high values for 1981-84, probably reflecting optimistic assessments of the impact of new agricultural development programmes in the north of the country, which subsidized fertilizer distribution.

(4) Cassava yields per hectare, Ghana. As a humid zone crop, cassava (which has benefited from research targeted on disease problems), appears likely to have improved. Ghana claims the greatest improvement over the period.

(5) Mineral fertilizer consumption, six countries. Mineral fertilizer policy is the most controversial element of agricultural policy. Government resources cannot support subsidization indefinitely; shortages breed bottlenecks, rent-seeking and inflated 
prices. Fertilizer is necessary for agricultural intensification, both in the eyes of its advocates and in those of most farmers (who, unless wealthy, are unable to obtain enough organic fertilizers). The import and manufacture of fertilizers are controlled, and so data are reliable. On a per hectare basis, after sharp increases until structural adjustment programmes began to bite in the 1980 s, consumption has apparently been maintained in spite of severe supply constraints. This is testimony to an absorptive capacity of small farmers.

(6) Value per hectare, Mali. A rising value of output per hectare was used in the Machakos study as an indicator of agricultural intensification. Unless expressed in local terms, such an indicator is at the mercy of global price trends where exports form a significant proportion of output. Mali's upward trend from the 1960s until the late 1980s may be reflecting cotton prices. However, upward trends sustained over more than 10 years - which occur more erratically in other countries-provide some indication of potential.

(7) Livestock per capita, six countries. With one major exception-Niger-the countries converged on a generally upward trend in livestock per capita which reflects not merely a preference for investing savings in animals, but buoyant markets for animal products and services.

Without confirmation from other data, it would be unwise to draw definitive conclusions from these series-except to affirm that a general hypothesis of agricultural decline is not supported.

\section{Unpacking Social Resilience}

The foregoing national-level analysis is superficial, makes much use of official data (which may not be reliable) and is restricted to one major region (the Sahel). At the village and household scale, more data are available that suggest answers to "why?", "how?", "where?" and "when?" questions. I cannot explore these adequately in a short paper. However, I believe that these long-term data series suggest new narratives of achievement that challenge the generalities often served up about Africa, are more specific to time and place (Scoones, 2001) and more valuable as pointers to policy (Scoones \& Toulmin, 1999). This is not to deny that in certain livelihood systems, indicators may suggest a long-term decline rather than achievement (Davies, 1996).

Three questions arise from this analysis: What is the nature of the resource that has enabled rural Africans to sustain themselves through shocks and adverse trends? What are the constraints? Can a better understanding of it contribute to policies, interventions, or governance?

\subsection{What is the Nature of the Resource?}

The persistence (and growth) of human communities has been remarkable in the Sahel, where for decades desertification has been believed to be eroding the natural resources and undermining the productive base. Persistence cannot therefore be attributed to natural resource endowments. Investment in land, labour or technology is relatively risky on account of environmental variability and constrained by household poverty. Yet persist they do-and in increasing numbers, notwithstanding the drought cycles of the 1970 s and 1980s, with almost every year's rainfall falling below earlier 30-year averages.

Since these environments have not been generally susceptible to high-input, high- 
yielding technological packages, it cannot in any general sense be attributed to a "green revolution". Risky rainfall has set a premium on drought-escaping (early maturing) varieties of cowpea and millet - the first developed on research stations and the second selected from indigenous inventories. ${ }^{9}$ Drought resistance is a character found in several indigenous sorghum varieties. More relevant than "miracle crops" is the popularity of animal traction for ploughing and carting, and mineral fertilizers. The first is a labour-saving technology. Paradoxically, demand for it appears after the extensive phase of shifting cultivation or bush fallowing has given place to permanent fields under higher population densities. ${ }^{10}$ Mineral fertilizers, a land-saving technology, expand in use when subsidies and efficient distribution are available, and decline when they are not. Average consumption in West Africa is low.

The environmental constraints and ambiguous role of new technology point to the possibility that persistence is mainly attributable to social resilience. I distinguish it from the commonly used terms, social and human capital, on the ground that they refer to assets (Ellis, 2000), whereas the resilience I wish to suggest is a strategic dynamic. As such it incorporates flexibility and adaptation. ${ }^{11}$

Social resilience is more than knowledge (indigenous or hybrid technical knowledge), more than productivity (primary or otherwise) and more than livelihoods as such. It is about the capacity to make strategies in response to shocks or trends, whose purpose goes beyond "coping" and "survival" to "flexibility" and "adaptation" (Davies, 1996; Mortimore \& Adams, 1999). ${ }^{12}$ Is it possible to generalize about it, perhaps for major agro-ecosystems? In a Sahelian context, the following capabilities are critical:

(1) Productive efficiency. Factor allocations are not a routine matter. Differences in asset portfolios among farmers or between villages are compounded by the localized distribution of rainfall and by events that interfere with farm work. ${ }^{13}$ Labour gives way to land as the limiting factor under demographically driven intensification. If capital becomes available, for example through credit, the equation changes again. Successful "performance" in crop or livestock production results from a judicious balance between social consensus and individual ambition. This is the fundamental skill required of Sahelian producers, who must operate in a less predictable environment than those living in more humid agro-ecological zones.

(2) Resource conservation. Scarce factors have to be allocated between long- and short-term productivity objectives. Technology alone is not enough. In Machakos, a "good" farmer terraces his or her fields, even on very gentle slopes; a "lazy" one fails to do so. In Kano, residual effects of manure distribution are taken into account for following years, and "fallow" means a failure to mobilize resources for fertilization.

(3) Accumulation. Output inevitably varies between good and bad years. Producing not on an annual but a longer term basis, sound management of food reserves, protecting stocks from damage, smoothing consumption, rationing and the wise use of prestations compensate for this variability.

(4) Diversification. Accessing resources outside the community, usually (unless wealthy) by means of migration, prioritizes having a diversity of options, available in response to either scarcity or opportunity, in a seasonally pulsating and unbounded resource space. Bilocal residence has long been a feature of Sahelian life.

(5) Accessing knowledge, information or vocational education. This extends the boundaries of livelihood choices from a core of indigenous knowledge (critical, for example, in using "famine foods" from natural or domesticated biodiversity in times of hunger). The ways of doing this are very specific to time and place. For example, 
Kenyan families make effective use of formal education, whereas the Senegalese prefer informal social networks.

(6) Adapting institutions, using the term widely to include, for example, the division of labour between the sexes and ages, the mobilizing of collective work groups, customary rights to natural resources (not only land, but also water, grazing and trees), individual obligations to patrons or community seniors and customary forms of gifts or exchange. It is clear that the rapid changes being experienced in Sahelian societies call for many adjustments on the basis of social consensus rather than individual action or regulation alone. Sometimes, authority may intervene, as in Kenya where the traditional Akamba mwethya group was adapted into a voluntary conservation work group. Elsewhere, adaptation is quite autonomous, as in northern Nigeria where traditional gayya working groups are changing into hired labour gangs.

The studies in Diourbel, Maradi and Kano-and their precursor in Machakos, Kenya (Tiffen et al., 1994)-suggest that the sources of social resilience are found at three levels: in individual actions, through the family and via community institutions. Individual actions that draw on human capital (knowledge, skills, health), including such things as opportunistic behaviour, competition for power or profit, contract negotiations and self-development, are often assumed to be in the ascendancy, at the expense of family and community, and driven of course by the pervasive market. But familiescharacterized as "networks of implicit contracts" (Netting, 1993)—continue to be the nexus of livelihood decisions made under the terms of continuous negotiation between members. Among these are decisions about the allocation of labour, the use of natural resource entitlements, productive investments and the sharing of benefits from primary production, in relation to natural resource-based livelihoods. Community institutions may appear today to be less important, but adaptation has been documented in work groups, local resource tenure and common pool resource management. Community actions may also control access to knowledge, and defence or negotiation of rights, ultimately affecting the relations between winners and losers. A simple hypothesis of individualization seems to be inadequate.

\subsection{What are the Constraints?}

It seems important, having turned the searchlight away from assets as such (natural resources, technology, the "five capitals"), to focus on a strategic dynamic of livelihood management, to try to identify the obstacles that constrain social resilience. These include:

(1) Dependency. Our Senegalese case shows the consequences of policy-generated dependency on the state for credit, technology, inputs and marketing, when such a programme proves to be financially unsustainable. I have suggested that Senegalese peasants are more adaptive than they are assumed to be in the circumstances, but it remains a valid question whether long-term development was helped or hindered by treating them as little more than state sharecroppers.

(2) Restrictions on livelihood options. In Africa it was customary for decades to deplore the "rural-urban drift", as purposive mobility for income diversification was called. This attitude was inherited from colonial times, when some governments forcibly controlled it; but restrictive practices on smallholders could extend to the rural arena also, for example by banning bush burning or tree cutting (Nigeria), inter- 
district trade in maize or coffee production for export (Kenya). The slow revolution to decentralized governance and participatory decision is in the right direction.

(3) Market failures. Both input and product markets are obstructed, for example in northern Nigeria by blocked supply chains, profiteering, illegal rent-seeking (such as road blocks), fuel scarcities and other factors (Ariyo et al., 2001). The removal of state control where private investors are not forthcoming tends to close options to producers. Beyond the authority of the African state, global trade is affected by protection or subsidies in the very countries that advocate open markets. Family farming, far from being unsuited to competition, has demonstrated its resilience under unfavourable conditions.

(4) Inadequate knowledge. In participatory workshops held with farmers, officials and researchers both in Kenya and in the West African countries, a need for more and better market or technical information was frequently and strongly voiced (Drylands Research, 2001). It seems that outsiders consistently underestimate the communication barriers that inhibit rural peoples' options. The mobile phone has considerably greater potential than the Internet in poor societies. ${ }^{14}$

(5) Poverty. Social resilience may be strong where individual or family resilience is nevertheless weak. This critique of optimistic scenarios of agrarian change such as that argued for Machakos (Murton, 1999; Tiffen et al., 1994) stands or falls on data showing temporal change in the distribution or depth of poverty, data which are difficult to compile, for a number of reasons. ${ }^{15}$ It is simplistic to assume that the greater the poverty, the less the resilience. For example, the negative correlation between size of landholding (a common poverty indicator) and productivity, observed widely including in Machakos, holds down to the smallest size. Life cycle effects have been found in individual wealth/poverty trajectories in northern Nigeria (Hill, 1972).

\subsection{Can a Better Understanding Contribute to Policies?}

William Allan observed that although most Africans were farmers, not all Africans were good farmers (Allan, 1965). Extending this idea to livelihood construction in general, it seems clear from the Sahelian cases that social resilience as I have defined it has contributed to the "narratives of achievement" exposed in long-term data and that, while new knowledge and technologies have often played a major role in development, there is a social dimension which would reward more systematic analysis. At the same time, it could address the nagging questions of social and economic differentiation and poverty traps, consistent with current interest in increasing democratic freedom and reducing inequality. Social resilience may exist at the level of the system or community, but not every family or individual may be resilient. A major policy question therefore concerns the location of social resilience within and between communities, and how to enhance the resilience of the most vulnerable. ${ }^{16}$

\section{From History to Policy}

The practical problem we face is that social resilience tends to be place- and timespecific, while policy-makers want solutions that are broadly applicable. Rather than telling them they must read countless case studies, deep in insight and intricate in detail, are there key properties and determinants of social resilience in drylands that can be employed in a cross-cultural framework? Is a universal typology practicable? Can 
social resilience be measured, quantified, or indexed? What are the necessary steps towards linking knowledge with policy?

According to some interpretations of long-term change, "peasants" sooner or later are the victims of capitalism; "I suspect that what we are witnessing in Nigeria is ... a final act of historical elimination" (Watts, 1983, p. 513). More recently, of smallholders faced by many challenges, it has been written: "It is anybody's guess how long they will cling to their peasant subsistence fallback, before they are geographically dissipated by policy neglect and out-migration or physically disseminated by civil war and famine" (Bryceson, 2000, p. 323). Is such a "victim" model justified?

I am a persistent optimist and I find it ironic that a view that promotes the capabilities of poor African families, on the basis of positive narratives of achievement, tends to come into conflict with both technocratic interventionism and views of peasants as victims, normally found on opposite sides of the political spectrum! Therefore, it should be said that the standpoint of this argument is not to minimize either the need for change or the reality of the constraints they face. However, a sound historical critique of performance during the past 40-100 years offers a basis for designing pro-poor policies that do not demean the integrity of smallholders' livelihood strategies. A good doctor both takes a history and makes a diagnosis. Development agents have tended to emphasize the diagnosis at the expense of the history. Now that data and methodologies have improved, it would be good to reverse the trend.

\section{Notes}

1. I write as a geographer on the borderline between environmental and social science. The implication of the above remarks-a move from agricultural technology through environmental management to a social resource-will I hope commend my argument to social anthropologists, historians, etc.

2. Similar contradictions have been observed globally (Lomborg, 2001).

3. Some consider, however, that drylands possess compensating advantages in a seasonal rhythm that allows cultivated soils a rest period, reduces the risk of leaching and acidification and permits the keeping of livestock throughout the year (by preventing trypanosomiasis).

4. The following paragraphs are based on research carried out with ESRC and DFID (NRSP) grants in 1993-97, based at the Department of Geography, University of Cambridge, and in association with the Department of Geography, Bayero University, Kano, Nigeria. W.M. Adams, Afolabi Falola, Frances Harris and other Nigerian colleagues participated.

5. The reorientation of Nigeria's structural adjustment policy to a liberalization of import controls and reduction of farm subsidies may have been influential in some reduction of momentum in the 1990s.

6. The Government of Niger bans farming in the Zone Nomade/Pastorale, which is defined as falling north of the $250 \mathrm{~mm}$ rainfall isohyet, although this boundary is reported to be encroached on. Our data apply only to the Department south of this line.

7. FAOSTAT (www.fao.org). The data have been analysed by Alexandratos (1995).

8. Draft study for the International Institute for Environment and Development (M. Mortimore, Family farming in West Africa: What can we learn from long-term data?, January 2003).

9. In Nigeria it is often difficult to establish the provenance of local varieties, as farmers exchange and crossbreed rather than seeking new seedstock. Improved maize has been taken up predominantly in the sub-humid zone.

10. In the KCSZ, the ridging plough (used both for land preparation and first weeding) became much more popular from the 1980s, with the rising use and cost of hired labour, improved market incentives and the spontaneous development of hiring teams (plough, bulls and skilled plough-boys).

11. Such a definition may be consistent with the observation that resilience is strong in the West African societies and weaker in some southern African drylands where HIV/AIDS is pandemic, and the family system has been undermined by labour migration for many decades. 
12. Davies distinguishes coping and adaptation as follows: "whereas coping is a characteristic of structurally secure livelihood systems, vulnerable ones are characterised by adaptation", despite admitting that "one person's coping strategy may be another's adaptive strategy" (Davies, 1996, pp. 58-59). I prefer to consider adaptation as a purposive, long- or mediumterm change in a livelihood system, responsive to trends seen as either positive or negative, as distinct from flexibility, which is the ability to make short-term changes in response to shocks or opportunities (Mortimore \& Adams, 1999). I do not consider it practicable to distinguish between strategies in terms of compulsion or choice, "push" or "pull".

13. Some used to think that African villagers in seasonal climates follow an invisible "social clock" which dictates the timing and even the nature of farming operations. Individuals may not seem to act independently of, for example, a decision to withdraw free-grazing animals from the fields before planting, or collective attendance at a funeral in the next village; but an appearance of regimented behaviour can be deceptive.

14. It is reported that improved access to mobile phones by poor producers (including women) has had a dramatic effect in Bangladesh.

15. These include: (1) an acute scarcity of baseline data; (2) an absence of agreed poverty indicators; (3) problems of compatibility over time during which the definition and social construction of poverty change; (4) changes in social variables, such as family size and obligations; and (5) a moving conception of poverty among scientists, from a former preoccupation with income to current interest in forms of deprivation.

16. This is a task for interdisciplinary science, because in a context of natural resource management, the linkages between resource mobilization, technology use and social or human capital are complex. Sheltering behind traditional disciplinary windbreaks is a betrayal.

\section{References}

Alexandratos, N. (Ed.) (1995) World Agriculture: Towards 2010. An FAO Study (Rome, FAO, Chichester, John Wiley).

Allan, W. (1965) The African Husbandman (Edinburgh, Oliver and Boyd).

Anon. (1997) World Atlas of Desertification, 2nd Edn (Nairobi, Arnold, for the United Nations Environment Programme).

Ariyo, J.A., Voh, J.P. \& Ahmed, B. (2001) Long-term Change in Food Provisioning and Marketing in the Kano Region, Drylands Research Working Paper 34, Drylands Research, Crewkerne.

Boserup, E. (1965) The Conditions of Agricultural Growth: The Economics of Agricultural Change under Population Pressure (London, Allen and Unwin).

Breman, H. \& de Wit, C.T. (1983) Rangeland productivity and exploitation in the Sahel, Science, 221, pp. 1341-1387.

Bryceson (2000) Disappearing Peasantries (London, Earthscan).

Copans, J. (1975) Sécheresses et Famines du Sahel. 1, Ecologie, Dénutrition, Assistance. 2, Paysans et Nomades (Paris, Masperro).

Davies, S. (1996) Adapatable Livelihoods. Coping with Food Insecurity in the Malian Sahel (London and New York, Macmillan and St Martins Press).

Downing, T.E., Mungai, D.N. \& Muturi, H.R. (1988) Drought climatology and development of the climatic scenarios, in: M.L. Parry, T.R. Carter \& N.T. Konijn (Eds) The Impact of Climatic Variations on Agriculture, Vol. 2 (Dordrecht, Kluwer Academic), pp. 149-174.

Drylands Research (2001) Livelihood transformations in semi-arid Africa 1960-2000, Proceedings of a Workshop Arranged by the ODI with Drylands Research and the ESRC, in the series Transformations in African agriculture, Drylands Research Working Paper 40, Drylands Research, Crewkerne.

Ellis, F. (2000) Rural Livelihoods and Diversity in Developing Countries (Oxford, Oxford University Press).

Faye, A. \& Fall, A. (2000) Région de Diourbel: Diversification des Revenus et son Incidence sur l'investissement agricole, Drylands Research Working Paper 22, Drylands Research, Crewkerne.

Faye, A., Fall, A., Mortimore, M., Tiffen, M. \& Nelson, J. (2001) Région de Diourbel: Synthesis, Drylands Research Working Paper 23e, Drylands Research, Crewkerne.

Grégoire, E. \& Raynaut, C. (1980) Présentation générale du Département du Maradi, Université de Bordeaux II, Bordeaux.

Harris, F. (1996) Intensification of agriculture in semi-arid areas: lessons from the Kano Close-Settled Zone, Nigeria, Gatekeeper Series 59, International Institute for Environment and Development, London. 
Harris, F.M.A. (1998) Farm-level assessment of the nutrient balance in northern Nigeria, Agriculture, Ecosystems and Environment, 71, pp. 201-214.

Hill, P. (1972) Rural Hausa. A Village and a Setting (Cambridge, Cambridge University Press).

Hill, P. (1977) Population, Prosperity and Poverty: Rural Kano 1900 and 1970 (Cambridge, Cambridge University Press).

Hulme, M., Doherty, R., Ngara, T., New, M. \& Lister, D. (2001) 'African climate change: 1900-2100', Climate Research, 17, pp. 145-168.

Lomborg, B. (2001) The Skeptical Environmentalist: Measuring the Real State of the World (Cambridge, Cambridge University Press).

Mortimore, M. (1989) Adapting to Drought, Farmers, Famines and Desertification in West Africa (Cambridge, Cambridge University Press).

Mortimore, M. (1993) Northern Nigeria: land transformation under agricultural intensification, in: C.L. Jolly \& B.B. Torrey (Eds) Population and Land Use in Developing Countries. Report of a Workshop (Washington, DC, National Academic Press).

Mortimore, M. (1998) Roots in the African Dust: Sustaining the Sub-Saharan Drylands (Cambridge, Cambridge University Press).

Mortimore, M. (2000) Profile of Rainfall Change in the Kano-Maradi Region, 1960-2000, Drylands Research Working Paper 25, Drylands Research, Crewkerne.

Mortimore, M. \& Adams, W. (1999) Working the Sahel: Environment and Society in Northern Nigeria London, Routledge.

Mortimore, M. \& Adams, W.M. (2001) Farmer adaptation, change and 'crisis' in the Sahel, Global Environmental Change, 11, pp. 49-57.

Mortimore, M., Harris, F. \& Turner, B. (1999) Implications of land use change for the production of plant biomass in densely populated Sahelo-Sudanian shrub-grasslands in northeast Nigeria, Global Ecology and Biogeography, 8, pp. 243-256.

Mortimore, M., Tiffen, M., Boubacar, Y. \& Nelson, J. (2001) Department of Maradi: Synthesis, Drylands Research Working Paper 39e, Drylands Research, Crewkerne.

Murton, J. (1999) Population growth and poverty in Machakos District, Kenya, The Geographical fournal, 165, pp. 37-46.

Mustapha, A.R. \& Meagher, K. (2000) Agrarian Production, Public Policy and the State in Kano Region, 1900-2000, Drylands Research Working Paper 35, Drylands Research, Crewkerne.

Netting, R.M. (1993) Smallholders, Householders. Farm Families and the Ecology of Intensive, Sustainable Agriculture (Stanford, Stanford University Press).

Raynaut, C. (1975) Le cas de la Région de Maradi (Niger), in: J. Copans (Ed.) Sécheresses et Famines du Sahel. Tome II. Paysans et Nomads (Paris, Librairie Francoix Maspero).

Raynaut, C., Koechlin, J., Brasset, P., Miranda, E. de, Stiglione, S. \& Cheung, F. (1988) Le Développement Rural de la Région au Village-Analyser et Comprendre la Diversité (Bordeaux GRID/Université de Bordeaux 2).

Scoones, I. (Ed.) (2001) Dynamics and Diversity. Soil Fertility and Farming Livelihoods in Africa (London, Earthscan).

Scoones, I. \& Toulmin, C. (1999) Policies for Soil Fertility Management in Africa London, Department for International Development.

Tiffen, M. (2001) Profile of Demographic Change in the Kano-Maradi Region, 1960-2000, Drylands Research Working Paper 24, Drylands Research, Crewkerne.

Tiffen, M., Mortimore, M. \& Gichuki F. (1994) More People less Erosion: environmental Recovery in Kenya (Chichester, John Wiley \& Sons).

Trevallion, B.M. (1965) Metropolitan Kano. Report on the Twenty year Development Plan 19631983, Newman Neame for the Greater Kano Development Authority, London/Kano.

Turner, B.L.I., Hyden, G. \& Kates, R.W.E. (1993) Population Growth and Agricultural Change in Africa (Gainesville, University Press of Florida).

Watts, M.J. (1983) Silent Violence: Food, Famine and the Peasantry in Northern Nigeria (Berkeley, University of California).

Wiggins, S. (2002) Smallholder farming in Africa: stasis and dynamics, in: D. Belshaw \& I. Livingstone (Eds) Renewing Development in Sub-Saharan Africa: Policy, Performance and Prospects (London, Routledge) pp. 101-120. 